\title{
In-Country Refugee Processing of Haitians: The Case Against
}

\author{
Bill Frelick
}

\begin{abstract}
Reviewing past experience with in-country processing in Haiti and its links to American interdiction policies, as well as the history of Cuban migration to the United States, this paper argues against in-country processing for Haitian refugees. The paper asserts that in-country processing in Haiti in the early 1990s was a failure, and arguably was used as a justification for returning to persecution far more people than it saved. The very existence of a small aperture through which relatively few selected individuals will be able to pass for legal admission to the United States is likely to erode the rights of many more Haitian asylum seekers seeking to leave spontaneously and, in particular, to serve to rationalize migration control measures that seriously compromise the fundamental principles of refugee law.
\end{abstract}

\section{Résumé}

Après avoir passé en revue l'expérience du passé de traitement sur place à Haïti et ses liens avec les politiques américaines d'interdiction, ainsi que les antécédents de l'immigration cubaine aux États-Unis, cet article s'oppose fortement à la politique de traitement sur place des réfugiés haïtiens. L'article soutient que le traitement sur place à Haïti au début des années 90 s'est soldé par un échec, et qu'il est permis de penser que, par la suite, cet échec a été utilisé comme justification pour renvoyer à la persécution beaucoup plus de personnes qu'il ne sauva. L'existence même d'une petite ouverture à travers laquelle un nombre relativement restreint d'individus sélectionnés pourra passer pour entrer légalement aux États-Unis, va très vraisemblablement éroder les droits d'un plus grand nombre de demandeurs d'asile haïtiens désireux de quitter le pays spontanément, et, en particulier, va servir à rationaliser des mesures de contrôle à l'immigration qui portent sérieusement atteinte à l'intégrité des principes fondamentaux du droit des réfugiés.

I $\mathrm{n}$ the context of deteriorating human rights conditions in Haiti and continuing interdiction and summary return of Haitian boat people, U.S. government agencies are discussing the possibility of re-initiating refugee processing from within Haiti. Based on past experience with incountry processing in Haiti as well as on principles of refugee protection, this paper argues that the existence of an incountry processing program might well prevent asylum seekers who leave Haiti irregularly from having a fair hearing on their claims while also not providing a viable alternative for people who are compelled by imminent threats to flee the country.

On April 11, 2003, government officials met with four nongovernmental organizations to discuss a wide variety of concerns relating to the treatment of Haitian refugees, asylum seekers, and immigrants. Officials at that meeting requested a statement from those agencies specifically on resettlement and processing of Haitian refugees. They sent that memorandum on June $23,2003 .{ }^{1}$ While this paper respectfully differs with the recommendations in that document, the agencies endorsing both that statement and this share the critique of past and present U.S. government practices toward Haitian refugees and asylum seekers as violating their rights. The agencies endorsing this statement fully support the opening statement in the June 23, 2003, paper: "The NGOs providing these recommendations are united in their belief that the United States must comply with its obligations under both U.S. and international law 
to provide protection to refugees who have a well-founded fear of persecution." All concerned NGOs agree that. practices of the U.S. with respect to Haitian asylum seekers, thus far, have fallen considerably short of meeting its obligations under U.S. and international law.

\section{The History of In-Country Processing in Haiti and Its Link to Interdiction}

From its inception, the in-country processing program in Haiti has been linked to U.S. interdiction policies. On January 31, 1992, the Supreme Court lifted an injunction on the forced repatriation of interdicted Haitians, and on the following day, February 1, the first Bush administration resumed forcibly repatriating Haitians. In-country processing began that same month. That was no mere coincidence. This became clear several months later, on May 24, 1992, when President George H.W. Bush issued the Kennebunkport Order, under which all interdicted Haitians would be returned summarily to Haiti without interviews or processing to determine possible refugee status. At the time of the announcement, the White House advised would-be refugees to apply at the U.S. consulate in Port-au-Prince for in-country refugee processing.

The mere existence of an in-country processing program was used to justify the new policy of summarily returning all interdicted Haitians with no screening. Although it was touted as an alternative to boat departure, the reality at the time was that only a handful of people were able to avail themselves of that alternative. Of the 279 Haitians who had applied since the inception of the program in February 1992, nine had been admitted to the United States by the end of May, an average of two per month. This rate was occurring as the Cedras dictatorship was crushing all dissent and while U.S. Coast Guard cutters were returning all interdicted Haitian asylum seekers.

A June 11, 1992, House hearing examined in-country processing in Haiti, at which point twelve Haitians had been admitted to the United States (out of 1,582 applicants). Then-Representative Stephen J. Solarz said that the Bush administration's use of in-country processing to justify summary return of interdicted Haitians was a "ludicrous argument." He said, "In the Soviet Union, Cuba, Vietnam, and Romania in-country processing has been an alternative option for those with the inclination, courage, and gumption to use it. But it has never been the exclusive option, and it is clear that making it the exclusive option does not conform to international law."

At the same Congressional hearing, Professor Harold Koh testified that it would be "suicide" for persons in the situation of Haitian boat people to attempt instead the in-country processing option. "To pursue this option," he said, "the asylee [sic] would have to leave hiding, pass numerous security road blocks, enter the heavily militarized capital city of Port-au-Prince, travel to areas surrounding the U.S. Consulate and Embassy that are especially dangerous given the high concentration of security forces, present and identify himself to the Haitian security forces before entering, subject himself to their scrutiny, engage in highly adversarial proceedings with U.S. immigration officials, then repeat the entire process several times before receiving a final determination on his asylum request."

On January 14, 1993, shortly before he was sworn in as president, President-elect Bill Clinton announced that he would continue the Bush administration's interdiction policy, telling Haitians, "Those who do leave Haiti directly by boat will be stopped and directly returned by the United States Coast Guard." He told Haitians that they had an alternative. "You can apply from within Haiti, through the United States embassy in Port-au-Prince.” Shortly after Clinton's announcement, the Coast Guard announced Operation Able Manner, surrounding Haiti with twenty-two U.S. Coast Guard cutters and navy ships, as well as deploying planes and helicopters for surveillance in order to ensure that no boats of Haitian asylum seekers eluded interdiction.

In fact, it had become even more difficult to pass through the eye of the in-country-processing needle than a few months earlier. Between the start of the program in February 1992 and the end of that year, 9,389 cases, representing 15,580 , persons had applied for the in-country processing program in Haiti; 61 cases, 136 people, were admitted to the United States. The Coast Guard interdicted 37,618 Haitian boat people in Fiscal Year 1992, the overwhelming majority of whom were summarily repatriated.

1993 was a particularly bad year for Haitian would-be refugees. Human rights abuses were widespread, yet Haitians had nowhere to flee. In-country processing was not a viable option for people being hunted down, but the existence of what on paper appeared to be an alternative justified summary interdiction and return. The hopelessness of boat escape was demonstrated by the precipitous drop in Haitian interdictions from the nearly 37,618 in FY 1992 to 4,270 in FY 1993, almost all of whom were summarily returned. Although the number of persons admitted through incountry processing rose in FY 1993 to 1,307, relative to the growing number of applicants the number admitted was paltry and amounted to little more than false hope for most. Nevertheless, the State Department reported to Congress that year that "refugee questionnaires were placed on U.S. Coast Guard cutters engaged in interdiction operations so that repatriated boat people would be made aware of the 
U.S. program and those with strong refugee claims could be brought quickly into the refugee processing program." ${ }^{2}$

With the failure of the Governors Island Agreement in October 1993, human rights conditions inside Haiti plummeted further. With the possibility of finding asylum through boat departure cut off, up to 800 persons a day began applying for in-country processing. This mechanism, slow moving at best, became completely overwhelmed by the numbers.

By May 1994, in-country processing had proven to be a complete sham-a smokescreen for refoulement. At that point, 54,219 applications had been filed representing nearly 106,000 people; only 10,644 cases had been decided, of which 9,827 had been denied, an approval rate of 7.7 percent of cases decided. But most cases never got as far as an interview with the Immigration and Naturalization Service (INS). The procedure required at least four separate interviews for screening and refugee status determination followed by additional visits for medical clearances, sponsorship assurances, issuance of Haitian passports and U.S. travel documents, and other travel arrangements. All visits required the applicants to wait at locked gates and pass various security guards. The Port-au-Prince and Les Cayes processing offices were located in close proximity to large military and police facilities. Although accommodations were made to permit INS-approved Haitians to leave the country without being required to approach the Haitian authorities for a Haitian passport, many of the most vulnerable people never applied for the in-country procedure for fear that doing so would expose them to danger, especially since many thought they would be required to approach the very authorities they feared to get passports. A total of 3,766 Haitians were admitted as refugees in FY 1994, which included cases adjudicated during the previous two years, but whose exit was delayed by the cumbersome process.

\section{Screening Standards Higher for Haitians}

The in-country screening standard was significantly higher than the international refugee standard of a well-founded fear of persecution. Starting in May 1994, interviews were granted only to applicants who met one of five criteria: (1) senior and mid-level Aristide officials; (2) close Aristide associates; (3) journalists or educational activists who had experienced significant and persistent harassment; (4) highprofile members of political and social organizations who had experienced significant and persistent harassment; or (5) others of compelling concern to the United States and in immediate danger. ${ }^{3}$

The criteria essentially required membership in a segment of the Haitian elite as well as a showing of significant and persistent harassment. Poor people, who bore the brunt of the Cedras regime's repression and who overwhelmingly constituted the ranks of the boat people, had virtually no chance. A U.S. embassy official involved in in-country processing said in an April 1994 interview, "We decide who gets placed into line [for an INS interview] and how to move cases that are INS-approved. If you are in a neighborhood that has been victimized en masse, you will not have a chance under U.S. law. You need to show individual targeting." In effect, applicants from neighbourhoods being victimized en masse, such as Cité Soleil, where individualized targeting was, in fact, occurring were excluded from the program. The same month, an NGO caseworker who screened cases for the INS said, "The person would at least have to have been arrested once to get an INS interview." 4 This clearly indicates a standard not required to establish refugee status under international law, which is based on a well-founded fear of future persecution, not necessarily based on a showing of past persecution.

The bias against non-elites went beyond the standards for screening applicants and adjudicating claims. It was based on capacity to travel and on having a mailing address, a place of residence, and, implicitly, literacy in a country with a high illiteracy rate.

The in-country processing program also, most importantly, required-ironically and perversely - that the applicant's fear of persecution couldn't be so high that he or she would be afraid to be seen standing in line outside the processing locations or that he or she was unable wait for the prolonged process to conclude.

In-country processing couldn't provide safety for applicants during the slow and highly visible procedure. As human rights conditions in Haiti deteriorated this became more and more obvious. On July 27, 1994, when commercial flights out of Haiti were cancelled, 1,857 INS-approved refugees were left stranded. Subsequently, the nongovernmental agencies pre-screening cases for the INS in Les Cayes and Cap Haitien stopped interviewing new cases, saying that there was no way to evacuate persons approved as refugees for U.S. admission. On August 1, 1994, Haitian police and paramilitary forces attacked a line of applicants waiting for refugee processing where pre-screening was still occurring in Port-au-Prince, beating and arresting a number of the applicants.

\section{Now and Then}

There is no reason to believe that many of these same problems would not recur if in-country processing were re-established in Haiti today. Given conditions in Haiti and available resources for such a program, would truly vulnerable Haitians have any better access to in-country processing now than they did then? Under conditions of appalling 
economic misery, endemic corruption and mismanagement, and uncontrolled political violence, would applicants be able to gain access to the program or expose themselves to additional risk while their claims were pending? A recent report by the National Coalition for Haitian Rights suggests that dissidents are subject to attack not only at the hands of so-called popular organizations, but also a corrupt and politicized police force. The September 2003 report observes:

Most notably, the numbers of attacks, acts of intimidation and outright assassinations against members of the opposition, human rights organizations and independent journalists have amplified in comparison to the late 1990s. Alarmingly, members of the national police force as well as so-called popular organizations (OPs) close to the government have been linked directly to many such violations that have contributed to the decline for respect for human right in general. ${ }^{5}$

An additional problem that in-country processing would face in 2003 that it did not confront in the 1992-94 period is the role of the home government. In 1992-94, the U.S. government did not recognize the Cedras regime, and proceeded with in-country processing without the cooperation of that government. However, in cases where the U.S. government does recognize the government of the home country, as it does in 2003 with the Aristide regime, it would be bound to seek the co-operation of that government in the in-country processing procedure, particularly in the issuance of passports or other travel documents. In this respect, in-country processing would be more problematic in 2003 than it was in 1994 with respect to fundamental refugee protection principles-i.e., it would compel a person who fears persecution at the hands of his or her government to approach that same government for permission to seek asylum from it.

Most importantly, in the event of a renewed mass exodus of Haitian boat people, would the mere existence of an in-country processing program, no matter how flawed or limited it might be, be used as a rationale for returning Haitians back to the place of persecution?

\section{Violation of Fundamental Principles of Refugee Law}

Article 33 of the Refugee Convention forbids the return of a refugee to a place where his life or freedom would be threatened-the principle of non-refoulement. The U.S. asylum system within the territory of the United States is built on this foundation - on the mandatory bar preventing governments from returning refugees to persecution, and on the corollary principle that a person so protected generally ought to have a status (asylum) which can lead to permanent protection in the form of citizenship. Yet this principle is openly violated by U.S. interdiction practices and was more subtly undermined by in-country processing in Haiti.

The international law bar on refoulement is absolute; but U.S. interdiction practice makes it discretionary. President George H.W. Bush's Kennebunkport Order, which authorized the United States to stop and board vessels on the high seas and to return their passengers to their countries of origin, added that "the Attorney General, in his unreviewable discretion, may decide that a person who is a refugee will not be returned without his consent." (Emphasis added.) The President does not hold the Attorney General to the 1951 Refugee Convention's command not to "expel or return ('refouler') a refugee in any manner whatsoever to the frontiers of territories where his life or freedom would be threatened."

Overseas refugee resettlement is not built on the foundation of non-refoulement at all. It is completely discretionary because resettlement is about admission, not removal. Because refugee admissions are completely discretionary, the U.S. government is under no legal obligation to admit any refugees from abroad, and it has wide latitude to determine which refugees are of "special humanitarian concern" to it sufficient to admit them as refugees.

Accordingly, U.S. officials in Haiti would not be required to admit every Haitian who approached its in-country processing centers with a well-founded fear of persecution. As it did in the early 1990s, U.S. officials could choose whom and how many it wished to take. It would be compelled to take not a single would-be refugee, no matter how strong his or her claim. As it did in the early 1990s, the U.S. government could create almost insurmountable vetting criteria that go well beyond the legal refugee definition and the regulations that govern asylum adjudication within the United States.

A discretionary refugee admissions program, therefore, does not come close to meeting international legal requirements to protect refugees. In-country programs are even more problematic. Since the applicant is already inside his or her home country, he cannot actually be a refugee at all at the time of applying for refugee status, and, logically, his denial cannot be called refoulement since he or she cannot be returned to a place where he or she is already present.

In-country processing linked to interdiction is the most dangerous combination of all. Haitian in-country processing in the 1990s-established to operate in conjunction with interdiction and summary return-was designed to create an exclusive track for Haitians seeking protection from persecution. This is particularly offensive to international refugee protection principles. Ordinarily, U.S. asy- 
lum adjudicators regard asylum seekers as having abandoned their claims if they opt for voluntary repatriation. The interdiction-and-return-to-in-country-processing scheme, however, is predicated on requiring repatriation in order to seek protection from that country. Where in-country processing programs are, in effect, designed as the only avenue for seeking protection, as they were for Haitians during key periods of the Cedras dictatorship, they are not just problematic, but manifestly harmful.

\section{Cuban In-Country Processing and Migration Controls}

The practical realities also make it clear that in-country processing has intrinsic limitations as a mechanism to protect people fleeing persecution at the hands of their own government. Long before in-country processing started for Haitians, Ricardo Inzunza, the deputy commissioner of the INS in the first Bush Administration, wrote in a 1990 law review article about the limitations of in-country processing in the Soviet Union, Cuba, and Vietnam. "Unfortunately, in most cases, those most in need of this remedy-those most vulnerable to abuses and with least access to any viable alternative-are least likely to be able to take advantage of it. Those in active flight are unlikely to get into the U.S. embassy, or even to it, without being noticed and/or arrested.... It is slow and many persons with a 'well-founded fear of persecution' simply cannot wait for such processing to be completed."

Whatever the value of in-country processing in Russia, Vietnam, or Cuba as a mechanism for rescuing people threatened with persecution while still living in their home countries, it ought, at best, to be considered as complementary to the right to seek asylum outside the country by other means, and not as a substitute for the right to seek asylum as embodied in Article 14 of the Universal Declaration of Human Rights. The scope of this paper does not permit an exhaustive examination of in-country processing in Russia and Vietnam and an analysis of whether or not it compromised the right to seek asylum (certainly the intent in creating the Orderly Departure Program out of Vietnam was to create an alternative to boat departures, but the existence of the program does not appear to have been used as a justification for summarily returning Vietnamese boat people to Vietnam), but because of the geographical similarities of Cuba and Haiti as Caribbean island nations and their proximity to the United States as a country of first asylum, it is worth examining in some detail in-country processing in Cuba and its links to migration-control measures.

The history of Cuban migration to the United States demonstrates the unique standing of Cubans in U.S. immi- gration and refugee policy as exiles from the only Communist country in the Western Hemisphere. Spontaneous waves of refugees ebbed and flowed between the $1959 \mathrm{Cu}-$ ban Revolution and 1965, but boat departures escalated sharply in October 1965 when President Lyndon Johnson gave a speech at the foot of the Statue of Liberty welcoming all Cubans "who seek freedom" to the United States. Cuban President Fidel Castro opened up Camarioca harbour, allowing a flotilla of boats to leave. The large and unmanaged migration flow prompted the United States to negotiate a migration agreement with Cuba in late 1965 that established criteria for determining which Cubans might board daily flights from Havana to Miami. The 1965 Memorandum of Understanding excluded all political prisoners and all draft-age men from the flights. Therefore, what became the largest "in-country processing" program in U.S. history-the Freedom Flights of the 1960s that brought more than 700,000 Cubans directly to the United States from 1965 until they were halted by Fidel Castro in 1973-was designed to exclude the most vulnerable people at highest risk of persecution. Testifying before a Congressional hearing in 1979 about those who arrived on the Freedom Flights of the 1960s, Virginia Dominguez said, "Many of those who came after 1965 were housewives and children, and were not actively political. They were not necessarily poor, or the victims of political persecution."

The cut-off of managed migration in 1973 again resulted in Cubans fleeing the island by raft and boat with the encouragement of the U.S. government, culminating in President Jimmy Carter's 1980 welcome of Cuban boat people "with an open heart and open arms" that resulted in a mass influx of more than 125,000 from the harbour of Mariel that summer. The presence of some criminals and mental patients among the other "Marielitos" and their sudden, massive, and disorganized arrival caused a sharper backlash than had occurred in 1965. On September 29, 1981, President Ronald Reagan issued Presidential Proclamation 4865, which authorized the high seas interdiction of boats carrying suspected undocumented migrants to the United States. Cuban migration slowed considerably during the Reagan and George H. W. Bush administrations. Between 1982 and 1992, the Coast Guard interdicted 5,311 Cubans, an average of about 480 per year, but brought them to the United States. They were paroled into the United States, and under the terms of the Cuban Adjustment Act of 1966 were generally able to adjust to permanent resident status after staying for one year. In-country refugee processing from Cuba began in 1987, but was a relatively modest program admitting an average of 2,261 per year from 1988 through 1992. 
U.S. migration policy toward Cubans shifted dramatically during the Clinton administration, a time of massive upsurge in boat and raft departures. For the first time, the United States initiated a policy of interdiction and return of Haitians, and explicitly linked that policy to the existence of in-country processing. On May 2, 1995, the Clinton administration announced that the Coast Guard would interdict Cuban rafts and boats, hold abbreviated shipboard screening, and repatriate screened-out Cubans. In language reminiscent of Clinton's first announcement of his Haitian interdiction policy, Attorney General Janet Reno accompanied the new Cuban interdiction and return policy by saying, "effective immediately, Cuban migrants intercepted at sea attempting to enter the United States, or who enter Guantanamo illegally, will be taken to Cuba, where U.S. consular officers will assist those who wish to apply to come to the United States through already established mechanisms. Cubans must know that the only way to come to the United States is by applying in Cuba."

Reno's announcement, particularly the last sentence quoted, demonstrated a breathtaking disregard for fundamental refugee principles. To suggest that persons who have fled persecution should return to the very country where they fear persecution as the only avenue to seek protection from that persecution is absurd. Yet that became official policy.

Later that year, the INS issued written guidance to its officers going on shipboard detail in the Florida Straits instructing them how to implement this policy. Essentially the same statement is read to Cubans interdicted today. Then, as now, they are directed to read the following statement: "You are being taken back to Cuba. You will not be taken to the United States." It is not specified whether the ships carrying the interdicted Cubans are already traveling back to Cuba as INS (now Department of Homeland Security, or DHS) assessments of the Cubans are taking place, but the opening sentence tells the Cubans this is the case, and suggests to them a certain inevitability about the process.

The Cubans are next told: "U.S. government officials in Havana will meet the ship and will provide information to you if you wish to apply to go to the United States through established migration programs." Then the Cubans are assured that it is safe for them to go back to Cuba. The statement reads: "The government of Cuba has provided a commitment to the United States that you will suffer no adverse consequences or reprisals of any sort for illegal departure or for making application for legal migration to the United States at the U.S. Interests Section." They are then, again, reminded that "only those people who are approved by the U.S. Interests Section in Havana can be assured of entry to the United States."
The statement tells the Cubans only that the Cuban government has agreed that Cubans will not suffer adverse consequences for illegal departure or for applying at the U.S. Interests Section; it is silent about Cuba's lack of assurances about other adverse consequences for political dissent or other underlying reasons for fleeing the country.

The statement closes with an ambiguous invitation to come forward with any concern about returning to Cuba. The word actually used in the Spanish announcement is asunto, which more accurately translates as "matter" rather than "concern" as written in the official English text of the statement. ${ }^{7}$ Although the interdicted Cubans are told that their asunto will be treated confidentially, the instruction to the INS officers only advises them to keep these interviews private and confidential "to the extent possible."

If a Cuban takes the initiative of approaching the INS officer, the memorandum instructs the officer to "arrange a meeting with that person." The odd choice of wording is specifically to avoid use of the terms "pre-screening" or "screening." In the meeting, INS officers are instructed to ask the Cubans whether they are aware of refugee processing at the U.S. Interests Section. If the Cuban persists in expressing a fear of return, the officer is instructed to apply a "credible fear of persecution standard." However, the instruction goes on to direct the officer: "In evaluating the objective basis for a person's fear under the credible fear standard in this program, you should consider the formal assurances made by the Cuban Government to the U.S. Government that no Cuban migrant will suffer adverse consequences or reprisals of any sort for irregular departure or for applying for refugee status, the monitoring of Cubans returned under this program by officials from the U.S. Interests Section, and the existence of an in-country processing program.”

The INS guidance requires its shipboard officers to perform two mutually exclusive functions: first, to conduct a sales pitch for in-country processing to convince the Cuban that it is safe to return; then, to act as an adjudicator to determine whether the same person has a credible fear of return. Directing the adjudicator to tell the applicant that it is safe to return hopelessly prejudices any such adjudication.

The United States concluded a migration agreement with Cuba in September 1994 whereby the United States agreed to admit 20,000 immigrants per year and Cuba agreed to prevent unauthorized boat departures. The agreement on its face put the U.S. government in the position of demanding that the Cuban government violate Article 13 of the Universal Declaration of Human Rights, which guarantees everyone the right to leave his or her own country. The September 9, 1994, agreement said that Cuba would "take effective measures in every way it possibly can to prevent 
unsafe departures using mainly persuasive methods." The language of taking measures "every way it possibly can," and explicitly not limited to persuasive methods, is chilling. Deputy Assistant Secretary of State Michael M. Skol, the chief U.S. negotiator in the talks, told the press, "We expect a dramatic reduction in departures.”

\section{Conclusion}

The agencies endorsing this statement support a generous immigration policy for Haitians provided there is no quid pro quo that requires the Haitian government to prevent its citizens from leaving the country in violation of international human rights principles.

The agencies supporting this statement also encourage the U.S. government to consider Haitian refugee processing from first-asylum countries in the region, including the Dominican Republic and the Bahamas.

The agencies supporting this statement remain fundamentally opposed to past and current U.S. interdiction practices because they do not afford asylum seekers an opportunity for fair hearings of their refugee claims, and because the U.S. government through the interdiction program does not recognize its obligations under Article 33 of the 1951 Refugee Convention.

For the same reasons that in-country processing in Haiti in the early 1990s was a failure, and arguably was used as a justification for returning to persecution far more people than it saved, in-country processing should not now be regarded as representing a genuine mechanism of protection for Haitians actively fearful of being persecuted. The very existence of a small aperture through which only a relatively few selected individuals will be able to pass for legal admission to the United States under the U.S. refugee admissions program is too likely to erode the rights of many more Haitian asylum seekers seeking to leave spontaneously and, in particular, to serve to rationalize migration control measures that seriously compromise the right to seek asylum itself.

This statement has been endorsed by the following nongovernmental organizations:

Amnesty International USA
Lawyers Committee for Human Rights
TransAfrica Forum
Immigration and Refugee Services of Americal
U.S. Committee for Refugees

\section{Notes}

1. The memorandum, written by Wendy Young and addressed to Matt Waxman of the National Security Council, was endorsed by the National Coalition for Haitian Rights, the National Immigration Forum, the U.S. Conference of Catholic Bishops, and the Women's Commission for Refugee Women and Children.

2. Bureau of Population, Migration and Refugee Affairs, Report to Congress on Proposed Refugee Admissions for Fiscal Year 1995.

3. Id., the screening criteria is outlined in the State Department's FY 1995 Report to Congress, and further elaborated in "Changing U.S.-Haitian Refugee Policy: New In-country Processing System; Shipboard Adjudications Resume," by Bill Frelick, Refugee Reports, Vol. 15, No. 5, May 31, 1994, at 2. Nevertheless, the INS Assistant Officer in Charge in Haiti at that time recently said that this standard was not actually implemented.

4. Id., at 4 .

5. "Yon Sèl Dwèt Pa Manje Kalalou: Haiti on the Eve of Its Bicentennial," National Coalition of Haitian Rights, September 2003, at 19.

6. Ricardo Inzunza, "The Refugee Act of 1980: Ten Years After-Still the Way To Go," International Journal of Refugee Law, Vol. 2, No. 3 (1990) 421-22.

7. Report on the First Three Years of Implementation of Expedited Removal, Center for Human Rights and International Justice, University of California, Hastings College of Law, note 357 , at 125-26, which includes the full text of the statement read to interdicted Cubans.

Bill Frelick is the director of Amnesty International USA's Refugee Program. Prior to joining Amnesty International, he was the director of the U.S. Committee for Refugees, which he served for eighteen years (1984-2002). 